\title{
Politicos Públicas de Educação: a (Des)articulação entre a União, o Estado e os Municípios
}

Pesquisadora: Maria Antonieta Dali 'Igna Instituição: Universidade Federal de Pelotas (UFPEL) Fonte financiadora: Instituto Nacional de Estudos e Pesquisas Educacionais (INEP)

Nos últimos anos tem sido intenso o debate em torno do papel de cada instância de governo: a União, os Estados e os municípios, na área da educação, principalmente no que diz respeito ao ensino fundamental obrigatório.

Historicamente, as províncias e depois os Estados foram os responsáveis pelo ensino primário, organizando seus próprios sistemas educacionais. Somente na década de 30 , foram levadas a efeito as primeiras iniciativas para dar à educação, no Brasil, um caráter nacional.

A Constituição de 1934, pela primeira vez, definiu papéis, atribuindo à União a competência para traçar diretrizes da educação nacional e elaborar um plano nacional de educação, de acordo com os quais os Estados e o Distrito Federal deveriam organizar seus sistemas de ensino. A participação prevista para os municípios res- 
tringiu-se à obrigatoriedade da aplicação de uma porcentagem mínima de recursos na educacação.

Nesse mesmo período, a municipalização do ensino era defendida pela Associação Brasileira de Educadores, como opção para o ensino fundamental, o que se repetiu a partir de 1946, nas acaloradas discussões que envolveram a elaboração da primeira Lei de Diretrizes e Bases do Ensino, a Lei $n^{8} 4.024 / 61$.

O tema voltou ao cenário nacional da década de 70 , por iniciativa dos governos militares. Nessa época, apoiados pela orientação de diferentes agências internacionais (USAID, ONU, Unesco, Banco Mundial, FMI), os governos de vários países da América Latina promoveram reformas educacionais, implantando diferentes modelos de descentralização: regionalização, nuclearização, municipalização e até privatização, como no Chile. Essas reformas têm sido objeto de uma série de estudos e pesquisas.

No Brasil, a descentralização tomou a forma de municipalização e foi implementada em dois momentos opostos: após a promulgação da Lei $\mathrm{n}^{0}$ $5.692 / 71$ e como programa dos governadores de oposição eleitos em 1986, sob diferentes formas e graus.

Essas experiências contribuíram para que se intensificasse o debate sobre a definição das com- petências de cada esfera de governo, quando das disputas que caracterizaram o último processo constituinte.

Hoje, a discussão sobre o papel de cada nível de governo e a sua articulação para a oferta do ensino fundamental se amplia, envolvendo professores, especialistas, pesquisadores, governantes e as mais diversas entidades. A municipalização mantém-se como uma opção, mas cresce cada vez mais a consciência de que o poder público, em seu conjunto, tem a responsabilidade pela educação no país e que somente mediante uma efetiva articulação, da parceria comprometida entre a União, os Estados e os municípios se poderá enfrentar a crítica realidade da educação brasileira.

Este estudo se propõe a analisar como têm se desenvolvido as relações entre a União, os Estados e os municípios na oferta do ensino fundamental; especificamente, como se concretizaram nos municípios de Pelotas e Canguçu, no Rio Grande do Sul, essas políticas de "ação supletiva, cooperação financeira e assistência técnica, ou regime de colaboração".

O período definido para o estudo, de 1970 a 1990, corresponde a um crescimento no desenvolvimento de políticas e programas governamentais na área educacional, abrangendo as três esferas do 
governo. Os dois municípios foram escolhidos por terem apresentado posturas diferentes diante das iniciativas do governo estadual em transferir os encargos e serviços com o $1^{\mathrm{Q}}$ grau, da zona rural para as administrações municipais (municipalização). Canguçu, em 1973, assumiu a responsabilidade pelas escolas estaduais da zona rural e, em 1987, municipalizou a merenda escolar, enquanto o município de Pelotas não aceitou nenhuma dessas propostas.

Para acompanhar as repercussões das políticas que regulam as relações entre a União, os Estados e os municípios, no que diz respeito à oferta do ensino fundamental, estão sendo analisados:

- os dados que permitem

avaliar a evolução do comporta mento do alunado (matrícula, índice de aprovação, reprovação, abandono e repetência), das con dições do corpo docente e da parti cipação de cada rede de ensino, es tadual, municipal e privada, na oferta do ensino de $1^{\circ}$ grau, para obter-se um quadro global do ensi no de cada município;

- os programas, projetos.convênios e planos de colaboração, co operação e ação supletiva, da Uni ão e do Estado, e os planos e rela tórios dos municípios;

— os balanços dos municípios.

Ao mesmo tempo, estão sendo realizadas entrevistas abertas com secretários municipais de educação, supervisores, orientadores e técnicos dos órgãos municipais de educação de Pelotas e Canguçu.

O estágio atual da pesquisa permite algumas constatações:

- a relação entre a União, o Estado e os municípios está centrada no repasse de recursos financeiros;

- há uma ocorrência maior de programas e, conseqüentemente, de repasse de recursos, entre os anos de 1982 e 1986;

- a característica principal dos programas e convênios é a sua descontinuidade. O único programa contínuo é o Programa de Auxílio ao Desenvolvimento do Ensino Municipal (POEM/PRADEM), do governo do Estado;

- mesmo existindo o POEM/ PRADEM desde 1973, a sua repercussão nas despesas municipais com educação vem decrescendo e não é expressiva. Em 1973, o auxílio do PÕEM representou para Canguçu $34,55 \%$ e para Pelotas $8,02 \%$ do total das despesas com educação, mas no ano de 1990 esteve reduzido para 6,4\% e $0,44 \%$, dessas despesas, respectivamente;

— no que se refere à evolução da participação das redes na oferta do ensino de $1^{\circ}$ grau entre os anos de 1975 (quando começam a ser computados os dados) e 1990, constata se, nos dois municípios, 
um pequeno crescimento percentual da rede estadual. A rede municipal, embora apresente redução no número total de matrículas em razão do êxodo rural e da redução populacional pela criação de novos municípios, tem aumentado sua participação no número de matrículas da zona urbana. Não se pode afirmar que esteja ocorrendo a municipalização do ensino de $1^{\circ}$ grau; pelo contrário, as duas redes, estadual e municipal, estão atendendo ao crescimento das matrículas na zona urbana.

Os dados coletados estão em fase de organização e interpreta- ção, a partir das condições que têm sido postas pela União e/ou pelo Estado para a assinatura de convênios com os municípios: aplicação dos percentuais previstos em lei na educação, valorização do corpo docente, criação do Conselho Municipal de Educação e, também, a partir dos resultados do processo ensino-aprendizagem (índices de evasão, reprovação e repetência). Os resultados serão discutidos com os órgãos municipais de educação de Pelotas e Canguçu, com a $5^{\mathrm{a}}$ Delegacia de Educação e com outras entidades envolvidas na pesquisa, antes de sua publicação. 